\title{
DAVe Tell
}

\section{Augustine and the "Chair of Lies": Rhetoric in The Confessions}

\begin{abstract}
Augustine's highly dramatized resignation as a professor of rhetoric in Book Nine of The Confessions has caused a number of hermeneutic problems for scholars seeking to claim Augustine as an important part of rhetorical histories. By situating the resignation in the context of Augustine's critique of Manichaean practices of speech, I argue that Augustine's resignation marks a fundamental affirmation of rhetoric-an act in which Augustine's deep commitment to the arts of rhetoric shines forth with uncommon brilliance.
\end{abstract}

Keywords: St Augustine, Confessions, professor of rhetoric, chair of lies

In your sight, I resolved not to make a boisterous break, but to withdraw the service of my tongue (ministerium linguae) from the language marts (nundinis loquacitatis).... [I]t seemed like outward show if we would not wait for the vacation time that was now so near, but would leave early a public profession (de publica professione), practiced before the eyes of all men.

Augustine, The Confessions, 9.2.2-3

\section{I}

n Book Nine of The Confessions, Augustine confessed rhetoric itself. Augustine had been a well-respected teacher of rhetoric until, upon his conversion, he decided that his vocation as a "seller of words" (venditor verborum) was incompatible with his new-found religious beliefs. ${ }^{1}$ In no uncertain terms,

${ }^{1}$ Augustine, The Confessions of St. Augustine, trans. John Kenneth Ryan (Garden

Rhetorica, Vol. XXVIII, Issue 4, pp. 384-407, ISSN 0734-8584, electronic ISSN 15338541. ( 2010 by The International Society for the History of Rhetoric. All rights reserved. Please direct all requests for permission to photocopy or reproduce article content through the University of California Press's Rights and Permissions website, at http://www.ucpressjournals.com/reprintInfo.asp. DOI: 10.1525/RH.2010.28.4.384. 
Augustine confessed that his conversion to Christianity compelled him to abandon his "chair of lies" (cathedra mendacii) in favor of a holier calling. James J. Murphy captures well the religious fervor with which Augustine disavowed his calling as a professor of rhetoric: "It would be only a slight exaggeration to say that in a sense [Augustine] was converted from rhetoric to Christianity." ${ }^{\prime 2}$

This conversion, of course, is one of the most troubling passages for those seeking to claim for Augustine an important place in the histories of rhetorical theory. Catherine Chin succinctly explains the dilemma facing such scholars. Augustine, she writes, was "a late Roman rhetor; yet rhetoric, both as a practice and a profession, is markedly problematic to the Augustine of the Confessions. ${ }^{1 / 3}$ Scholars have responded to this problem with strategies of containment. Murphy, for example, asks scholars to consider Augustine's resignation as a professor of rhetoric as exceptional, as out of keeping with his larger project of adapting the secular ars rhetorica for Christian purposes. ${ }^{4}$ Calvin Troup, advocating another strategy of containment, argues that we should understand Augustine's resignation not as a rejection of rhetoric tout court, but a rejection of the historically specific and theoretically unique rhetoric of the Second Sophistic. ${ }^{5}$ In both cases, the strategy has been to contain and circumscribe Augustine's resignation. It seems that there has been a widely shared impulse that if Augustine is to remain a significant part of rhetorical histories, his rather embarrassing dismissal of rhetoric must be contained and limited; it must be shown that this dismissal is marginal, exceptional, and not related to Augustine's otherwise important contributions to rhetorical theory.

I argue just the opposite. I believe that Augustine's resignation of the professoriate is not an exceptional moment in his rhetorical theory; rather, it marks the culmination of a critique of Manichaean practices of speech that spans the entirety of The Confessions. At the heart of

City: Image Books, 1960), 9.5.13 (hereafter cited parenthetically in the text using the Latin abbreviation, Conf.).

2James J. Murphy, "Saint Augustine and the Christianization of Rhetoric," Western Journal of Communication 22 (1958): 24-29 (p. 26).

${ }^{3}$ Catherine M. Chin, "Christians and the Roman Classroom: Memory, Grammar, and Rhetoric in Confessions X," Augustinian Studies 33.2 (2002): 161-83 (p. 162).

${ }^{4}$ Murphy, "Saint Augustine and the Christianization of Rhetoric," cited in n. 2 above, p. 27.

${ }^{5}$ Calvin L. Troup, Temporality, Eternity, and Wisdom: The Rhetoric of Augustine's Confessions (Columbia: University of South Carolina Press, 1999), 11-35. 
this critique is Augustine's indictment of a distinctively Manichaean rhetorical form: the profession (professio). ${ }^{6}$ The definitive characteristic of professio is loquacity (loquacitas) and, as the above epigraph suggests, it is, precisely speaking, the selling of loquacity that the post-conversion Augustine relegates to his sinful past. To be sure, critiques of loquacity, talkativeness, or chattering were something of a cultural commonplace, the locus classicus being Plutarch's Of Garrulity, or Talkativeness.? Augustine, however, brings to the standard critique a radical edge: while Plutarch complains that loquacity disables memory and undermines persuasion, Augustine claims that loquaces are mutos; that it is, in very real ways, silent. This is a peculiar claim, and I will interrogate it at length below. For the moment, however, I want to emphasize that Augustine's critique of the Manichaean professio as a rhetorical form invites us to reconsider his resignation of the "chair of lies": while it is certainly true that Augustine resigned his job as a professor of rhetoric (professione rhetorica), I argue that this resignation is better understood as a rejection of professing rather than a rejection of rhetoric (Conf., 9.4.7). Indeed, because Augustine believed that profession, as a rhetorical form, eventuated in silence, I argue that we can read his resignation as an act undertaken on behalf of rhetoric itself. So understood, the resignation is no longer an embarrassment to be explained, but an achievement to be heralded-an act in which Augustine's deep commitment to the arts of rhetoric shines forth with uncommon brilliance. And if this is the case, we should understand that when Augustine confesses rhetoric in Book Nine of The Confessions, he does not do so in the sense that Murphy suggests; it is not a confessio peccatorum - an acknowledgement of sin that leads to conversion. Rather it is a confessio laudis-an affirmation of his belief in rhetoric. ${ }^{8}$

The argument proceeds in three sections. First, I account for the standard moves in the interpretation of Augustine's resignation. I argue that the resignation cannot be accounted for with recourse to

${ }^{6}$ The Manichaeans, Augustine writes, "Profess themselves": "They become vain in their thoughts and 'profess themselves to be wise,' by attributing to themselves things that are yours" (Conf., 5.3.5).

${ }^{7}$ Plutarch, Of Garrulity, or Talkativeness (The Online Library of Liberty, 2008); http: / / oll.libertyfund.org/?option=com_staticxt\&staticfile=show.php\%3Ftitle=1214 \&chapter $=92421 \& l a y o u t=h t m l \& I t e m i d=27$. See also, Michel Foucault, Fearless Speech (Los Angeles: Semiotext(e)), 63.

${ }^{8}$ On the ambiguity of the verb confiteor and the noun confessio in Augustine's work, see James J. O’Donnell, Augustine: Confessions. 3 vols. (New York: Oxford University Press, 1992); http://www.stoa.org/hippo/comm1.html. 
either Augustinian theology or the historical backdrop of the Second Sophistic. Second, I advance my own explanation of the resignation, suggesting that it be understood in terms of his critique of the Manichaean professio. Third, I argue that the professio is best understood as the form of expression proper to a particular subjectivity, the distended self. It is precisely this relationship between the professio and the distended self that explains Augustine's insistence that Manichaean practices of speech are functionally silent, and it is thus this relationship that allows us to read the resignation as an affirmation of rhetoric. I'conclude by suggesting how this analysis might help us revise the rhetorical lessons we learn from Augustine.

\section{READING THE RESIGNATION}

It is not surprising that Augustine's famous desertion of the professoriate has troubled scholars seeking to make sense of Augustine as a rhetorician who holds an important place in histories of rhetorical theory. Two dominant strains of interpretation contain and mitigate the force of Augustine's resignation by explaining it with recourse to either Christian theology or rhetorical history. Although these interpretations are distinct in many ways, it is their shared assumption that I wish to foreground here: both see in Augustine's resignation of the professoriate a critique of rhetoric to be explained rather than an affirmation of rhetoric to be celebrated. I attend to each explanation in turn.

The fact that Augustine abandoned his post as a professor of rhetoric immediately following his conversion-and that he did so with religious fervor-has led some scholars to argue that Augustine's resignation constitutes a theological critique of rhetoric. On this score, it is Augustine's conversion to Christianity that marks the death knell for the privileged place of rhetoric in his thought. Classicist Harold Hagendahl, for example, suggests that "rhetoric is not exempted from the contemptuous censure of profane culture" that is the Confessions. ${ }^{9}$ Such conclusions, however, are at pains to reconcile themselves with Augustine's post-conversion celebrations

${ }^{9}$ Harold Hagendahl, Augustine and the Latin Classics (Stockholm: Almqvist \& Wiksell, 1967), 557. Or, see Murphy: "Rhetoric at the end of the fourth century was associated with things pagan, Roman, non-Christian" (Murphy, "Saint Augustine and the Christianization of Rhetoric," cited in n. 2 above, p. 26). 
of "profane culture" in general, and his continued dedication to the ars rhetorica in particular. ${ }^{10}$ To the latter point, the fourth book of De doctrina Christiania provides Augustine's "most complete statement on rhetorical theory" and appears to completely reconcile Christianity and rhetoric. ${ }^{11}$ In one of the most quoted sentences of the text, Augustine writes,

For since by means of the art of rhetoric both truth and falsehood are urged, who would dare say that the truth should stand in the person of its defenders unarmed against lying, so that they who wish to urge falsehoods may know how to make their listeners benevolent, or attentive, or docile in their presentation, while the defenders of truth are ignorant of that art?

Augustine concludes that the art of rhetoric should be learned and deployed by Christians "for the uses of the good" and "the service of truth."12 Augustine's resignation, then, cannot be explained with recourse to a fundamental tension between Christian theology and rhetorical practice. While this tension certainly motivated such thinkers as Jerome and Tertullian, for Augustine the art of rhetoric was never reducible to a profane practice fit only for the civitas terrena.

Michael Leff and James Murphy have forwarded a slightly different reading of the relationship between Augustinian rhetoric and Augustinian theology. In their own ways, they each argue that Augustine's rhetorical project was one of adaptation; it was the work of appropriating the secular ars rhetorica for the holy purposes of the Church. ${ }^{13}$ In so far as one is dealing with De doctrina Christiana, this is a highly defensible thesis. ${ }^{14}$ Yet, if scholars such as Hagendahl have

\footnotetext{
${ }^{10}$ Augustine on the celebration of culture: "Lord, I have loved the beauty of thy house" (Augustine, City of God, trans. Henry Bettenson (London: Penguin, 1984), XXII.21); hereafter cited parenthetically using the Latin abbreviation, DCD. Brown notes: "For, if the material world, and with it, the human body, had been a perfect gift of God, it could never be treated as second-best": Peter Brown, Augustine of Hippo: A Biography, 2nd ed. (Berkeley: University of California Press, 2000), 327.

${ }^{11}$ Michael C. Leff, "St. Augustine and Martianus Capella: Continuity and Change in Fifth-Century Latin Rhetorical Theory," Communication Quarterly 24.4 (1976): 2-9 (p. 4).

${ }^{12}$ Augustine, On Christian Doctrine, trans. D. W. Robertson (Indianapolis: BobbsMerrill, 1958), 4.2.3 (hereafter cited parenthetically by its Latin abbreviation, DDC).

${ }^{13}$ The language of adaptation is Murphy's ("Saint Augustine and the Christianization of Rhetoric," cited in n. 2 above, p. 27).

${ }^{14}$ Augustine himself seems to endorse this thesis: "When the Christian separates himself in spirit from their miserable society, he should take this treasure [the liberal disciplines] with him for the just use of teaching the gospel" $(D D C, 2.40)$.
} 
difficulty accounting for Augustine's later affirmation of rhetoric, ${ }^{15}$ scholars who celebrate Augustine's adaptation of rhetorical theory for Christianity typically have trouble accounting for The Confessions. Leff and Murphy, for example, each celebrate Augustine's formulations of a uniquely "Christian" rhetorical theory," but both pass over in silence Augustine's resignation. ${ }^{16}$ In Rhetoric in the Middle Ages Murphy does mention Augustine's contempt for his "chair of lies," but suggests that focusing on this contempt "may obscure" Augustine's very real contributions to rhetorical theory made in De doctrina Christiana.$^{17}$ It is as if the Christianization of rhetoric requires ignoring the passages in the Confessions that suggest that Augustine converted from rhetoric to Christianity.

In sum, the relationship between theology and rhetoric in Augustine's work is, at the least, a vexed relationship. The ability of Leff and Murphy to largely reverse Hagendahl's thesis is perhaps evidence that we cannot explain Augustine's resignation of rhetoric by focusing on the relationship between theology and rhetoric. ${ }^{18}$ This is not to say that Augustine's theological beliefs play no part in his resignation of the "chair of lies." They clearly do. Yet I do not believe that we can explain the resignation with sole recourse to theological categories. For too many years and for too many scholars this recourse has suggested that the post-conversion Augustine divided

${ }^{15}$ Hagendahl seems to assume that Augustine simply changed his mind between the disavowal of rhetoric in the Confessions and its re-affirmation in De doctrina Christiana. Although Augustine did change his mind on a number of substantial issues over the course of his writings (see Robert Markus, Saeculum: History and Society in the Theology of Augustine (Cambridge: Cambridge University Press, 1988)), James O'Donnell has argued that speech is not one of them: See O'Donnell,Confessions, cited in $\mathrm{n} .8$ above, 2:28.

${ }^{16}$ Leff, "St. Augustine and Martianus Capella," cited in n. 11 above, and James J. Murphy, "Saint Augustine and the Debate About a Christian Rhetoric," Quarterly Journal of Speech 46.4 (1960): 400-10. Murphy even lists the works of Augustine relevant to the rhetorician: the Confessions is notably absent. James J. Murphy, "The Metarhetorics of Plato, Augustine, and McLuhan: A Pointing Essay," Philosophy and Rhetoric 4 (1971): 201-14 (p. 205). See also Patton, who provides an in-depth consideration of Augustine's rhetorical theory and practice with no mention of Augustine's disavowals of the art in The Confessions: John H. Patton, "Wisdom and Eloquence: The Alliance of Exegesis and Rhetoric in Augustine," Central States Speech Journal 28 (1977): 96-105.

${ }^{17}$ James J. Murphy, Rhetoric in the Middle Ages: A History of Rhetorical Theory from Saint Augustine to the Renaissance (Berkeley: University of California Press, 1974), 47-48.

${ }^{18}$ Arendt argues that academic thought has, since its inception, been plagued by a series of reversals, all of which indicate a certain inattentiveness to historical events and actual practices: Hannah Arendt, The Human Condition (Chicago: The University of Chicago Press, 1958), 292-93. 
the world into the sacred and the profane, either embracing the former and dismissing the latter or deploying the former to transform the latter. Such was not the case. ${ }^{19}$

A second explanation for Augustine's resignation of the professoriate suggests that it was a rejection of the rhetorical practices of the Second Sophistic. In this vein, Calvin Troup suggests that what Augustine rejects upon his conversion is not rhetoric as such, but the historically specific rhetorical practices of the Second Sophistic. ${ }^{20}$ Troup is careful to note that Augustine does not even reject the whole of the Second Sophistic, but only those portions of it that would falsely divide philosophy from rhetoric. ${ }^{21}$ For once philosophy and rhetoric were sundered it was but a short theoretical step to the dichotomization of form and content. On this view, as Murphy notes, it was precisely Augustine's "firm espousal of a union between meaning and expression that marks his rejection of the sophistic" and explains his denunciation of the professoriate. ${ }^{22}$ Rhetorician Christine Mason Sutherland agrees; she argues, "It was precisely the sophistic divorce of style from content of which [Augustine] felt he must repent." She concludes that Augustine's conversion effectively "rescued" him from the "false division between words and the truth, between form and content, between style and matter." ${ }^{23}$

Scholars of this persuasion tend to explain Augustine's contributions to rhetorical theory in direct opposition to the practices of the Second Sophistic. While the sophists divorced wisdom and eloquence, the marriage of form and content is the highest goal of Augustinian rhetoric. Murphy, for example, argues that the first task

${ }^{19}$ The fundamental problem with this position is that the post-conversion Augustine did not divide the world (saeculum) into the distinct categories of the sacred and profane. Augustine argues that sacred and profane are "intermixed with one another in this present world" (DCD, X.32, XVIII.54). See also Dave Tell, "Augustinian Political Theory and Religious Discourse in Public Life," Journal of Communication and Religion 30 (November 2007): 213-35.

${ }^{20}$ An early explanation of this thesis can be found in Murphy's "Saint Augustine and the Christianization of Rhetoric," cited in n. 2 above. It is more fully explained in his Rhetoric in the Middle Ages, cited in n. 17 above, and subsequently widely accepted. Troup explains this thesis in detail: Troup, Temporality, Eternity, and Wisdom, cited in n. 5 above, pp. 11-35.

${ }^{21}$ Troup, Temporality, Eternity, and Wisdom, cited in n. 5 above, pp. 14-15.

${ }^{22}$ Murphy, Rhetoric in the Middle Ages, cited in n. 17 above, pp. 47-48.

${ }^{23}$ Christine Mason Sutherland, "Love as Rhetorical Principle: The Relationship between Content and Style in the Rhetoric of St. Augustine," in H. A. Meynell (ed.), Grace, Politics, and Desire: Essays on Augustine (Calgary: University of Calgary Press, 1990), 142, 152. 
of the Augustinian orator is to unite form and content. ${ }^{24}$ Troup concludes that the lesson we are to learn from Augustine's evacuation of the professoriate is this: "[T] he value of rhetoric [is] to be determined by its association either with wisdom or foolishness." ${ }^{25}$ Sutherland puts it most cogently:

For if there is one thing that emerges more clearly than anything else from these works [De doctrina Christiana and The Confessions]-so far as rhetoric is concerned-it is Augustine's deep conviction that there can be no separation between style and content; such disjunction, it seems to me, was considered by Augustine to be a disunity belonging to the province of evil. ${ }^{26}$

On one level, Murphy, Troup, and Sutherland are absolutely correct: Augustine did critique the rhetorical excesses of the Second Sophistic and he did, throughout The Confessions, emphasize the need for wisdom to attend and authorize eloquence..$^{27}$ On another level, however, I believe there is something more at stake in Augustine's resignation than a critique of sophistic practices. For if this was the sum of Augustine's concerns, his resignation would be, rhetorically speaking, insignificant. The insistence that wisdom and eloquence be united is, by the fourth century, hardly a newsworthy contribution to rhetorical theory-Augustine could not possibly have missed this precise point as he scoured Cicero's writings. ${ }^{28}$ In sum, reading Augustine's resignation vis-à-vis the Second Sophistic risks reducing The Confessions' contributions to rhetorical theory to a re-articulation of a Ciceronian commonplace.

Reading Augustine's resignation as a rejection of either profane culture or the Second Sophistic, then, precludes us from recognizing the resignation as a fundamental affirmation of rhetoric. I believe that the resignation-and The Confessions more generally-marks a deep commitment to the arts of rhetoric-a commitment that cannot

\footnotetext{
${ }^{24}$ Murphy, "Saint Augustine and the Christianization of Rhetoric," cited in n. 2 above, p. 28.

${ }^{25}$ Troup, Temporality, Eternity, and Wisdom, cited in n. 5 above, p. 30.

${ }^{26}$ Sutherland, "Love as Rhetorical Principle," cited in n. 23 above, p. 140.

${ }^{27}$ For example, when Augustine encounters Cicero's Hortensius he notes: "... nor did it impress me by its way of speaking but rather by what it spoke" (Conf, 3.4.7). See also Conf., 5.13.23, in which Augustine laments his early practices of listening to the preaching of Ambrose: "I hung eagerly on his words, but I remained uninterested in his subject matter."

${ }^{28}$ Cicero challenges the dichotomization of form and content in all three of his major works: De inventione, 1.1.1, De oratore, 1.4.20-22, and Orator, 3.13-15. See Troup, Temporality, Eternity, and Wisdom, cited in n. 5 above, p. 17.
} 
be adequately captured by insisting that Augustine Christianized a secular form or provided one more iteration of a rhetorical commonplace. To recognize this affirmation, however, we must contextualize Augustine's resignation of the professoriate not in terms of Christian theology or Sophistic practices, but in terms of Manichaean practices of speech. For it is the Manichaeans rather than the sophists who are the primary antagonists of The Confessions.

\section{A RHETORICAL READING OF THE RESIGNATION}

In Book One of The Confessions, immediately before Augustine launches into his account of his sinful infancy, he makes a seemingly paradoxical remark that will serve as the foundation for his critique of Manichaean practices of speech: "What have we said, my God, my life, my holy delight? Or what does any man say when he speaks of you? Yet woe to those who keep silent concerning you, since even those who speak much are as the dumb" (Conf., 1.4.4). Augustine is here suggesting that speaking about God is both necessary and futile. This conundrum is a commonplace of Augustine's thought and finds its most concise expression in De doctrina Christiana: "although nothing worthy may be spoken of Him, [God] has accepted the tribute of the human voice and wished us to take joy in praising him with our words" $(D D C, 11)$. Yet the last line of the quotation- "even those who speak much are as the dumb" - suggests that Augustine is here not simply concerned with the incapacities of human language to describe the ineffability of God. He is suggesting that the obligation to speak of God may be compromised in two ways. One may default on this obligation to speak through either silence or its functional equivalent: "speaking much." Indeed, the force of this passage is Augustine's counter-intuitive suggestion that to speak much is functionally equivalent to silence (mutus): as Watts renders the passage, "those that speak most, are dumb." ${ }^{29}$ Lest the reader miss this initial lesson, Augustine repeats the relationship between excessive speech and silence again in Book Seven: "For me, O Lord, that was a sufficient answer to those men, themselves deceived and deceiving others, dumb yet talking much [loquaces mutos]" (Conf., 7.2.3; emphasis mine).

\footnotetext{
${ }^{29}$ Augustine, Confessions, trans. William Watts, 2 vols. Loeb Classical Library (Cambridge: Harvard University Press, 1912), I.IV. O'Donnell emphasizes the force of this oxymoron by noting that, throughout Augustine's works, "mutus offers the natural antonym for loquax": O'Donnell, Confessions, cited in n. 8 above, 2:27.
} 
The men in question were loquaces mutos, or, more accurately, they were mutus because they were loquax. Sheer talkativeness resulted, for these men, in silence.

The logic by which "talking much" is equated with "silence" is certainly not self-evident, and I will explain this equivalence at length below. For the moment, however, I wish to emphasize that commentators agree that the referent of both passages- "those that speak most" and "those men"- are the Manicheans. Classicist Gillian Clark, for example, suggests that "Augustine uses loquaces of people who have much to say, like the Manicheans, but all of it mistaken or trivial: almost 'the chattering classes.' ${ }^{\prime \prime 30}$ Jean-Bethke Elshtain notes that so long as Augustine was under Manichean influence, "he remained 'all words.'"'31 The Manicheans were a small but influential third- and fourth-century heretical Christian sect with whom Augustine identified for the nine years immediately preceding his conversion to Christianity. ${ }^{32}$ In The Confessions the Manicheans were Augustine's primary antagonists and their chief vice was an excess of speech. ${ }^{33}$ Loquacitas, O'Donnell notes, was always a "pejorative" term for Augustine, and it was, in The Confessions, the "fault charged to the Manichees." ${ }^{\prime 34}$ Indeed, insofar as the Manicheans play a significant role in The Confessions, their significance derives from their loquaciousness. Even their views on the substantiality of evil, which Augustine will refute in Books IV-V, are of secondary importance when compared to this primary attribute: the Manicheans were

${ }^{30}$ Gillian Clark, "Commentary" in Augustine: Confessions Books I-IV, ed. Gillian Clark (Cambridge: Cambridge University Press, 1995), 88.

${ }^{31}$ Jean Bethke Elshtain, Augustine and the Limits of Politics (Notre Dame: University of Notre Dame Press, 1995), 14.

${ }^{32}$ Heretic is used here as a historically descriptive term rather than a normative or evaluative term. Although, Brown: "To an African Catholic, the Manichees were the 'heretics' par excellence." Brown, Augustine, cited in n. 10 above, p. 43. For an overview of the theological differences between the Manicheans and Augustine see Scott MacDonald, "The Divine Nature," in Eleonore Stump and Norman Kretzmann, eds., The Cambridge Companion to Augustine (Cambridge: Cambridge University Press, 2001), 71-90 (pp. 73-75), and Brown, Augustine, pp. 35-49. O'Donnell suggests that prominence of Augustine's narration of his nine year battle with the Manicheans in the Confessions makes it seem as though this battle between Christianity and Manichaeism was the "interpretive key to his whole life." James J. O'Donnell, "Augustine: His Time and Lives," in Stump and Kretzmann, eds., The Cambridge Companion to Augustine, pp. 8-25 (p. 10).

${ }^{33}$ Vaught: "Augustine reserves his most sustained attack for the founder of the Manichean sect." Carl Vaught, The Journey toward God in Augustine's Confessions: Books I-VI (Albany: State University of New York Press, 2003), 121.

${ }^{34} \mathrm{O}$ 'Donnell, Confessions, cited in n. 8 above, 2:27-28. 
too talkative. Augustine writes, "And so I fell in with certain men [Manichaeans], doting in their pride, too carnal-minded and glib of speech (nimis et loquaces), in whose mouth were the snares of the devil" (Conf., 3.6.10).

O'Donnell provides a perfect description of the Manicheans as they are represented in The Confessions: they "rattle on, their language out of control. ${ }^{\prime \prime 35}$ So loquacious were the Manicheans that nearly every time Augustine mentions them he emphasizes the sheer proliferation of their talk. He describes the writings of their founder, Mani, as "ravings" (Conf., 5.3.6); he describes them as "vain talkers" (Conf., 8.10.22) whose books are filled with "long-spun-out tales" (Conf., 5.7.12); and in their attempt to sway the young Augustine to Manichaeism they "boomed forth your name at me so many times and in so many ways, by the voice alone and by books many and huge." The various names of their deities, Augustine continues, were "never absent from their mouths." They were "always saying, 'Truth! Truth!' Many times they said it to me" (Conf., 3.6.10; emphasis mine). The Manichean teacher Faustus casts light, by exception, on Augustine's appraisal of the rest of the Manicheans. Augustine recounts that he was pleasantly surprised to learn that Faustus was "not one of those wordy fellows ... who attempted to instruct me in these matters but said nothing" (Conf., 5.7.12).

Nor is this critique of Manichean speech limited to The Confessions; in The City of God Augustine dismisses "the silly talk, or rather the delirious raving, of the Manicheans. They would not have babbled like this if they had believed in the truth" (DCD, XI.22). The excessive character of Manichean speech, however, is perhaps most evident in Augustine's treatise against Julian-a Pelagian whom Augustine accused of supporting Manichaeism: "Does talking give you so much pleasure that you must try by a superabundance of words to prove something we confess and teach, as though we denied it?"'36

The Manichean heresy, then, was both a theological and a rhetorical heresy. The theological heresy is well known. Insofar as Manichaeism was a rhetorical heresy, it results from the excessiveness of their speech: they rattled on; they offered instruction, but said nothing; they were given to a superabundance of words; above all, they were loquaces mutos-dumb yet talking much. It seems that,

\footnotetext{
${ }^{35} \mathrm{O}$ 'Donnell, Confessions, cited in n. 8 above, 2:27.

${ }^{36}$ Augustine, Saint Augustine: Against Julian, trans. Matthew A. Schumacher, ed. Roy Joseph Deferrari. Vol. 35 (New York: Fathers of the Church, Inc., 1957), 214.
} 
for Augustine, the sheer loquaciousness of the Manicheans rendered their speech silent.

The rhetorical heresy, however, must not be considered apart from the theological heresy. Augustine's critique is not simply that they speak a lot, but also that they divorced wisdom from eloquence. Thus O'Donnell: "the Manichees are talkative, but their talkativeness is de facto silence, for what comes forth is not the Word, but mere words. ${ }^{\prime \prime 37}$ For $\mathrm{O}^{\prime}$ Donnell it seems it is as if Manichean speech is silenced not because of its excessive character, but because of its empty content-it was all form. Troup would agree with this conclusion; he suggests that the Augustinian critique of speech is directed only towards those who would divide wisdom from eloquence. Yet, just as the rhetorical heresy cannot be separated from the theological heresy, the theological heresy cannot be separated from the rhetorical heresy. What $\mathrm{O}^{\prime}$ Donnell and Troup miss in their suggestion that the functional silence of the Manicheans resulted wholly from the falsity of their words is the fact that the theological heresy of folly is not prior to the rhetorical heresy of excessive, loquacious speech. Augustine is insistent that it is not simply that folly leads to loquaciousness, but, and this is his point, that loquaciousness also leads to folly. The theological heresy and the rhetorical heresy are, in other words, intractably intertwined and the former cannot claim logical or temporal priority over the latter. This is evident when we consider that Augustine's critique of Manichaean speech draws on Proverbs 10:19: "Where there are many words, transgression is unavoidable." ${ }^{\prime 38}$ In this instance it is Manichaean loquaciousness that leads to folly and not vice-versa. We can only conclude that the Manicheans' folly resulted both in and from a particular rhetorical practice-professio-and it was this practice that rendered their speech silent.

This, then, is the critique of speech that will recur throughout The Confessions: faulty speech is not merely the consequence of faulty reasoning, but also the cause of faulty reasoning. The particular fault of the Manichaean professio that Augustine indicts is its excessivenessa fault that he captures with the term loquax - "talkative, prating, chattering, loquacious, full of words." ${ }^{39}$ The radical character of Augustine's critique stems from his assertion that loquacity is not sim-

${ }^{37} \mathrm{O}$ 'Donnell, Confessions, cited in n. 8 above, 2:398.

${ }^{38}$ On Augustine's reliance on Proverbs 10:19, see O'Donnell, Confessions, cited in n. 8 above, 2:28.

${ }^{39}$ Charlton T. Lewis and Charles Short, A Latin Dictionary (Oxford: Clarendon Press, 1879), http:/ / www.perseus.tufts.edu/cgi-bin/ptext?doc=Perseus\%3Atext\%3A 1999.04.0059\%3Aentry\%3D\%2326984. 
ply speech divorced from wisdom, but it is, in some sense, silent: non-speech. "Those that speak most, are dumb." It is because Augustine's Confessions, from start to finish, rejected this chattering, this non-speech, that his resignation of the professoriate and the professio can be recognized as an affirmation of rhetoric.

At this point we must ask by what counter-intuitive logic is excessive speech functionally silent? To answer this question we must confront the Augustinian assumption that particular forms of speech are linked to particular forms of the self. Examining the character of the Manichaean self from which profession springs will enable us appreciate, in greater detail, why loquacity is silent and, therefore, why Augustine's resignation constitutes an affirmation of rhetoric.

\section{THE AUGUSTINIAN SELF AND ITS EXPRESSIONS}

Upon reading Cicero's (now lost) Hortensius, Augustine relates that he was "stirred up and enkindled and set aflame to love, and pursue, and attain and catch hold of ... wisdom itself" (Conf., 3.4.8). Thus inspired, Augustine began reading the "Holy Scriptures," but immediately abandoned them because they lacked the dignity of Cicero's eloquent exhortations to philosophy. The problem, Augustine insists, was not with the "humble style" of the scriptures, but rather with his own "swelling pride" (Conf., 3.5.9). Throughout The Confessions, pridefulness is connected with practices of speech. Here, his own pride prevented his appreciation for the plain-styled scriptures; elsewhere it will be the pride of the Manicheans that leads them into excessive speech. In this the Manicheans are exemplary of The Confessions as a whole; throughout the text the over-estimation of one's self-pride (superbia) — leads to vanity (vanitas), which, in turn, is always accompanied by an unrestrained loquacity. Indeed, the Manichaean loquacitas is associated with vanitas no fewer than seventeen times in The Confessions. ${ }^{40}$ It is as if excesses of the self were also and automatically excesses of speech. ${ }^{41}$ This association of

40 "Vanitas is linked with loquacitas at least 17x in [Augustine's] works" (O'Donnell, Confessions, cited in n. 8 above, 2:27). This association might find its most direct expression in Book XVI of The City of God in which Augustine considers the relationship between the faults of character that led to the tower of Babel and the attendant consequences for speech: "Since a ruler's domination is wielded by his tongue, it was in that organ that his pride was condemned to punishment" (XVI.4).

${ }^{41}$ On vanitas in Augustine see Robert J. O'Connell, Images of Conversion in Augustine's Confessions (New York: Fordham University Press, 1996), 57-58. On the pro- 
a mismanaged self with mismanaged speech forms a powerful part of Augustine's critique of profession. In this section I explore the two basic modalities of the Augustinian self, and modalities of speech proper to these selves.

The decisive characteristic of the Augustinian self is its loves and the most important characteristic of Augustinian love is its function as a coupler: love transforms the self by joining the self to that which is loved. ${ }^{42}$ This transformation of the self takes one of two modes, because there are, for Augustine, fundamentally only two kinds of love: the love of God and the love of self:

There are, then, two loves, of which one is holy, the other unclean; one turned towards the neighbor, the other centered on the on self; one looking to the common good ... the other bringing the common good under its own power, arrogantly looking to domination; one subject to God, the other rivaling him. ${ }^{43}$

Augustine's "catalogue of contrasts" continues, but the essential point is that all loves are reducible to two-the love of God (caritas) and the love of self (cupiditas) - which, Robert Markus notes, stand in "radical opposition" to each other. As the above catalogue might suggest, the two terms (caritas and cupiditas), although radically opposed to each other, are nonetheless remarkably pliant and polysemous for Augustine. The best Markus can do is to describe the two loves as "loving God or loving something else." ${ }^{\text {"4 }}$

The love of anything other than God is rooted in pride. ${ }^{45}$ Such a love manifests itself not simply in narcissism as one might expect, but also in a love for the things of this world-for the things of this

gression from superbia to vanitas $\mathrm{O}^{\prime} \mathrm{C}$ onnell writes: "That lust to excel ... tends to draw vanity into the orbit of pride, superbia" (p. 59). I develop this at length below.

${ }^{42}$ "Augustine understood human beings in terms of their longings, that what they long for is what defines them." John von Heyking, Augustine and Politics as Longing in the World (Columbia: University of Missouri Press, 2001), 3. Augustine: "What else is love except a kind of life that binds, or seeks to bind, together some two things, namely the lover and the beloved." Augustine, On the Trinity: Books 8-15, trans. Stephen McKenna (Cambridge: Cambridge University Press, 2002), 8.10.14.

${ }^{43}$ Augustine, The Literal Meaning of Genesis, trans. John Hammond Taylor (New York: Newman Press, 1982), 11.15.20.

${ }^{44}$ Markus, Saeculum, cited in n. 15 above, p. 68. Augustine: "So much less does he love you who loves anything else" (Conf., 10.29.40).

${ }^{45}$ "Perverse self-love, rooted in pride, is the basic disorder in the human self" (Markus, Saeculum, cited in n. 15 above, p. xviii). For Augustine's account of the relationship of pride to self-love see The Literal Meaning of Genesis, 11.15.19. 
world and the self share one decisive characteristic: createdness. ${ }^{46}$ Neither the self nor the things of this world are the Creator and thus the love for either counts as "loving something else" and is a fundamentally misplaced love and a form of pride. Misplaced though it might be, Augustine recognized that the love of this world is inevitable. ${ }^{47}$ Because love is a coupler, the love of the world joins the self to the world and diminishes the self by dispersing it, by joining it to the world and thus spreading it out into the world. This dispersion of the self is so complete that the self, having loved the world, can no longer distinguish itself from the world. ${ }^{48}$ The self has been radically and completely dispersed and distended: "Behold my life is a distention, or distraction" (Conf., 11.29.39)..$^{49}$

It is important to note, however, that the distended self is not simply the consequence of misplaced love (cupiditas instead of caritas); it is also the result of disordered love. Because the love of the world is inevitable the important point for Augustine is to love the world in the correct proportion and with the proper degree of intensity: "This is true of everything created; though it is good, it can be loved in the right way or in the wrong way-in the right way, that is, when the proper order is kept, in the wrong way when that order is upset" (DCD, XIV.22).

Augustine determines the proper order of loves with his use/enjoyment (uti/frui) distinction. Some things, Augustine relates, are to

\footnotetext{
${ }^{46}$ Thus Augustine describes the Manicheans, who for him are "swollen with pride" (self-love), thus: "They change your truth into a lie, and they worship and serve the creature rather than the creator" (Conf., 5.4.5).

${ }^{47}$ See Brown, Augustine, cited in n. 10 above, p. 324: "Augustine had come to expect the Christian to be aware of the tenacity of the links that would always bind him to this world."

${ }^{48}$ "Yet the force of love is so great that the mind draws in with itself those things upon which it has long reflected with love, and to which it has become attached by its devoted care, even when it returns in some way to think of itself" (Augustine, On The Trinity, 10.5.7).

${ }^{49}$ Augustine: "To be sure, man did not fall away from his nature so completely to lose all being. When he turned toward himself, however, his being became less complete than when he clung to Him Who exists supremely. Thus to forsake God and to exist in oneself-that is, to be pleased with oneself-is not immediately to lose all being; but it is to come closer to nothingness" (DCD, XIV.13). Arendt explains: "Through an improper independence "I lose the unity that holds me together by virtue of which I can say 'I am.' I thereby become dispersed in the manifoldness of the world and lost in the unending multiplicity of mundane data." Hannah Arendt, Love and Saint Augustine, ed. Joanna Vecchiarelli Scott and Judith Chelius Stark (Chicago: University of Chicago Press, 1996), 23.
} 
be enjoyed for their own sake, others are to be used for the sake of those things which are to be enjoyed. To enjoy something is "to cling to it with love for its own sake" while to use something is to approach it with a "transitory love" useful for "obtaining that which you love" for its own sake (DDC, 1.3.3-4, 1.35.39). Both things used and enjoyed are loved, but with different degrees of intensity. While things worthy of enjoyment are to be loved for their own sake, used things, although not loved for their own sake, are nonetheless the proper objects of a lesser "transitory" love: "we love those things by which we are carried along for the sake of that toward which we are carried" (DDC, 1.35.39).

For Augustine, the only thing to be enjoyed (loved for its own sake) is God. ${ }^{50}$ Everything else in the world is to be loved with a "transitory" love and "referred" to God, who is to be loved for his own sake. ${ }^{51}$ Augustine thus concludes that it is proper to love the things of this world because "these things are goods and undoubtedly they are gifts of God. But if the higher goods are considered the only goods, or are loved more than the goods which are believed to be higher, the inevitable consequence is fresh misery and an increase of the wretchedness already there" (DCD, XV.4). The conclusion Augustine reaches is this: caritas and the proper dependence upon God requires not only the proper object of love, but also the proper ordering of love. ${ }^{52}$ Thus Augustine prays in The City of God: "Order in me my love" (DCD, XV.22).

50 "The things which are to be enjoyed are the Father, the Son, and the Holy Spirit" (DDC, 1.5.5). "But if you cling to that delight and remain in it, making it the proper end of your rejoicing, then you may truly and properly be said to be enjoying it. And this kind of enjoyment should not be indulged except with reference to the Trinity, which is the highest good and immutable" (DDC, 1.33.36). "Rest in him, and you will in truth have rest" (Conf., 4.12.18).

${ }^{51}$ The proper way to "use" something to "enjoy" God is to "refer" all things to God: "For in order that a man may know how to love himself an end [God] has been established for him to which he is to refer all his action" $(D C D, 10.3)$. For Augustine, God is the Summum Bonum (highest good) "to which we refer all our actions, which we seek for its own sake, not for any ulterior end, and the attainment of which leaves us nothing more to seek for our happiness" $(D C D, 8.8)$. Brown: "[T] 'to refer', or 'relate', is central to Augustine's discussion of human activity; and for Augustine, of course, this human activity ... can only reach fulfillment when it can take its place in a harmonious whole, where everything is in relation to God." P. R. L. Brown, "Saint Augustine," in Beryl Smalley, ed., Trends in Medieval Political Thought (New York: Barnes and Noble, Inc., 1965), 7.

${ }^{52}$ Markus: "To know what a man's disposition is in regard to a particular object, we need to know not only whether he loves it, but also, or rather, in what way he loves it" (Saeculum, cited in n. 15 above, p. 66). 
This meditation on Augustine's ordering of loves is important because it sheds light on the two modalities of the Augustinian self. On the one hand, Augustine insists that the phenomenological result of disordered or inordinate loves is the experience of restlessness. ${ }^{53} \mathrm{It}$ is precisely this restlessness of the inordinate lover, in fact, that defines the distended self. In Book Four of The Confessions Augustine recalls his youth in which he did "not know how to love men as men should be loved." This inability to love properly led directly to restlessness: "Therefore I raged, and sighed, and wept, and became distraught, and there was for me neither rest nor reason" (Conf., 4.7.12). Or consider Augustine's description of his country retreat at Cassiciacum. There, "far from the madding world [aestu saeculi] we found rest in you" (Conf., 9.3.5). The Latin aestus signifies "an undulating, waving, boiling, tossing motion" and is a word often used to describe the ceaseless movements of the seas, the epitome of restlessness. ${ }^{54}$ Rivers and seas are powerful metaphors for Augustine precisely because their endless movement so perfectly mirrors the restlessness of the distended self. 55 "If Adam had not fallen away from you," Augustine writes, "from his veins there would not have flowed that salt sea water, the human race, so deeply active, so swelling in storms, and so restlessly flowing" (Conf., 13.20.28). ${ }^{56}$ This, then, is the phenomenology of Augustine's distended self: the self is dispersed into the world through inordinate loves and thus tossed about by the world.

On the other hand, the person of rightly ordered loves possesses a self that is happy and at rest: "[W]e direct our course towards him with love so that in reaching him we may find our rest, and attain happiness because we have our fulfillment in him" (DCD, X.3) ${ }^{57}$ The ordinate lover is coupled with God. This coupling is not as complete as the joining of the inordinate lover to the world. Love for God is not precisely a means of being joined to God, but rather a means of

53 "Many are miserable because they are in love with things that should not be loved, and they become even more miserable when they enjoy them" (DCD, VIII.8).

${ }^{54}$ Lewis and Short, A Latin Dictionary, http://www.perseus.tufts.edu/cgi-bin/ ptext?doc=Perseus \%3Atext\%3A1999.04.0059\%3Aentry\%3D\%231405.

${ }^{55}$ Augustine thus refers to the "river of human history" (On The Trinity, 4.16.21).

${ }^{56}$ "For then there shall be no more of this world, no more of the surgings and restlessness of human life, and it is this which is symbolized by the sea" (DCD, XX.16). Also: The civitas Dei is "on pilgrimage in this world as though in a flood" (DCD, XV.26).

${ }^{57}$ The goal toward which all loves aim is rest: "For the soul wishes to be and it loves to find rest in things that it loves" (Conf., 4.10.15). 
"clinging to God" (inhaerere Deo). ${ }^{58}$ Just as pridefulness results in the diminution and distention of the self, so the love for God results in a fullness of the self: "[T]he good angels did not turn to themselves, who had less being, but to Him Who supremely is, and that, cleaving to Him, their own being was enlarged by participation in Him" (DCD, XII.9). ${ }^{59}$ Just as Augustine figures the diminished self as "dispersed," so he figures this process of "enlargement" as a process of gathering: He praises God who "gathers me together again from that disordered state in which I lay shattered in pieces" (Conf., 2.1.1).

Further, just as the distended self is experienced as restless, so the gathered self is experienced as restful: "You have made us for yourself, and our heart is restless until it rests in you" (Conf., 1.1.1). Both clauses of this famous sentence express the dependence of the creature upon the Creator. The first clause announces the dependence- "you have made us for yourself" - while the second describes the existential consequences of this dependence: because the human condition is one of creaturely dependence, humanity will be at rest only insofar as it clings to the Creator through love. Thus Augustine: "In themselves they are but shifting things; in him they stand firm" (Conf., 4.12.18). Because rest is opposed to movement, it is precisely the sempiternal changelessness of God that provides rest for those who cling to him: "You are surpassingly the Selfsame, you who change not, and in you there is rest, forgetful of all labor" (Conf., 9.4.11). ${ }^{60}$

We have, then, in Augustine two possible selves: on one hand the independent, prideful, vain, distended, and restless self that loves the world and, on the other hand, the dependent, gathered, enlarged, whole, and restful self that clings to God. Each of these subject positions entails its own forms of linguistic expression and it is to these that I now turn.

${ }^{58}$ The notion of "clinging to God" is extremely important in Augustine's thought. Although references to "clinging" pervade Augustine's work, the concept receives its most direct treatment in The City of God XII.1: "Therefore the correct reply to the question, 'Why are the one sort happy?' is 'Because they cling to God'; and to 'Why are those others wretched?' the reply is, 'Because they do not cleave to him.'”

${ }^{59}$ Thus Burke's quip: "In Thyself, Lord, (am) I myself." Kenneth Burke, The Rhetoric of Religion (Boston: Beacon Press, 1961), 57.

${ }^{60}$ The importance of resting in God might be judged from the sheer frequency with which Augustine confesses the changelessness of God. In The Confessions, changelessness is far and away God's most important attribute and it was Augustine's inability to conceive of this changelessness that for so long kept him from Christianity. See for example: $3.6 .10 ; 4.11 .16 ; 4.15 .25 ; 7.4 .6 ; 7.15 .21 ; 7.20 .26 ; 8.3 .6 ; 10.5 .7$. 
Augustine writes that the Manicheans "profess themselves": "They become vain in their thoughts and "profess themselves to be wise,' by attributing to themselves things that are yours" (Conf., 5.3.5). "Profession" (professio) is the mode in which the vain express themselves. It is here important to remember that vanity (vanitas) is, for Augustine, a shorthand term to capture the shallowness of the distended self. To be prideful, to be too concerned with oneself, is to find oneself shallow, dispersed, without substance: vain. ${ }^{61}$ The distended self, then, professes itself.

The act of profession is defined by Augustine in two ways. He suggests it is characteristic of the Manicheans (and of Mani in particular) and it is opposed to the practice of confession:

It is vanity to make profession (profiteri) of these worldly subjects even when they are known, but it is piety to make confession (confiteri) to you. Hence this devious character [Mani] spoke at length (multum locutus) on natural philosophy only to this effect, that when refuted by others who had learned the truth concerning such things, they would clearly recognize what sort of knowledge he had. (Conf., 5.5.8)

Note first that profession is opposed to confession. While the former is associated with pride and is the expression of the distended self, the latter is an expression of dependence and thus a form of clinging to God: "The distinction between profession and confession is important because its first prong enables the intellect to turn away from God, while the second permits the will to return to the sustaining ground of its existence." ${ }^{\prime \prime 2}$ Profession is thus the expression of independence, pride, and self-love, while confession is an expression of dependence. It is not surprising, then, that Augustine later contrasts confession with presumption: "I would be able to detect and distinguish how great a difference lies between presumption and contrition [praesumptionem et confessionem]" (Conf., 7.20.26). This binary will persist throughout The Confessions; confession is always opposed to any form of expression-such as profession or presumption - that would suggest the independence of the self. The attitude towards oneself, then, is decisive for determining the expressions of the self. The selfloving and prideful person professes; the dependent person confesses.

${ }^{61}$ Augustine notes that when the self is distended through the love for the world, the human heart then "carries about throngs of vanity" (Conf., 10.35.57). O'Donnell, Confessions, cited in n. 8 above, 2:296, suggests that vanity is characteristic of Augustine's Manicheans throughout The Confessions. p. 121.

${ }^{62}$ Vaught, The Journey toward God in Augustine's Confessions, cited in n. 33 above, 
O'Donnell emphasizes this connection between the self and its mode of expression: both profession and confession denote "not only the speech itself, but the predisposition that makes ... speech possible." ${ }^{\prime 63}$ The mode of expression, in other words, is a direct result of the self that is speaking.

The inset quotation is valuable for a second reason: it indicates the nature of profession. Augustine records that Mani-the "professor" in the above quotation-was multum locutus: he was talkative; his speech was characterized by loquacious excess. This is the point: the loquacity that Augustine critiques throughout The Confessions is the product of a distended self. In this sense it is important to recognize that Augustine consistently associates the prideful and distended self with the loquacity he deplores: "I was already the leading student in the school of rhetoric [rhetoris], and in my pride I rejoiced and I was swollen up with vanity" (Conf., 3.3.6). This passage is not exceptional; as I noted above, Augustine consistently associates loquacity with vanity. One of the most explicit is found in his description of those who are "swollen with pride": "A talkative man loves lies. What gives him pleasure? Only talking. He does not even listen to what he is saying; all that matters is to keep talking. It is not possible for a person like that to be guided aright." ${ }^{\prime 64}$ The distended self is the loquacious self, concerned only with proliferation of talk- "all that matters is to keep talking." Augustine's account of the Manichean teacher Faustus is another example of the recurring association between a prideful self and loquacity. Faustus was an exceptional Manichean; unlike the others he was "properly modest" and thus "not one of those wordy fellows ... who attempted to instruct me ... but said nothing" (5.7.12).

Moreover, the loquacity which is the object of Augustine's critique is continually associated with restlessness, the existential reality of the distended self. Consider, for example, Watts' translation of Augustine's famous opening: "Our heart cannot be quieted [inquietum] till it may find repose [requiescat] in thee." ${ }^{\prime 65}$ The generally excellent translation of John K. Ryan, ${ }^{66}$ which in this case translated inquietum as "restless," speaks to the extent to which the tension

${ }^{63} \mathrm{O}^{\prime}$ Donnell, Confessions, cited in n. 8 above; http://www.stoa.org/hippo/ comm1.html.

${ }^{64}$ Augustine, "Exposition of Psalm 139," in Expositions of the Psalms (Enarrationes in Psalmos), ed. Boniface Ramsey (Hyde Park: New City Press, 2004), 296.

${ }^{65}$ Augustine, Confessions (trans. Watts), 1.1.

${ }^{66}$ Although there is debate regarding translation, Ryan's translation is usually followed within Communication Studies. See, for example, Troup, Temporality, Eternity, and Wisdom, cited in n. 5 above. 
between loquacity and quietness is, throughout The Confessions; correlated to the tension between restlessness and rest. This correlation is confirmed in the closing paragraphs of The Confessions in which Augustine prays for pacem quietus (Conf., 13.35.50) —translated "the peace of rest" by Ryan and "the peace of quietness" by Watts. It is not surprising, then, that Augustine describes the loquacity of the Manicheans as "exhausting" (Conf., 3.6.10), for the rest Augustine seeks is defined precisely against the loquacity of the Manicheans. The most direct link between restlessness and loquacity, however, comes in Book Five. Augustine writes, "The wicked, who are without rest, may go their way and flee from you" (Conf., 5.2.2). The Latin that Ryan translates above as "wicked" is "inquieti iniqui," or, as Watts translates it, "unquiet naughty people." ${ }^{67}$ In this instance loquacity is the decisive characteristic of the distended self. This is, $\mathrm{O}^{\prime}$ Donnell notes, the "closest [Augustine] comes to identifying 'inquietude' with wickedness." ${ }^{\prime \prime 8}$

Pride distends the self, renders it vain, and by spreading it out into the world pride also diminishes the self. This distended self professes, and these professions are marked by loquacious excess. This, however, is not all: the excesses of speech, in turn, further distend the self. Augustine notes that his rhetorical education "carried [me] towards vanity, and estranged [me] from thee, O my God" (Conf., 1.18.28). Moreover, when Augustine describes the "sound and clatter" of the Manicheans as "exhausting" (Conf., 3.6.10), he is again suggesting that the excesses of speech contribute to the restlessness and thus the distention of the self. Loquacity is, then, both the expression and the foundation of the distended self. The sins of the self and the sins of language, then, feed each other in a vicious circle: excesses of speech distending the self, a distended self loquaciously chattering.

The reciprocal nature of the relationship between loquacious profession and the distended self is important to emphasize, if only as a corrective to those scholars who would temper Augustine's critique of speech by suggesting that he is critiquing only speech that is empty of content. Recognizing the reciprocity between loquaciousness and the distended self allows us to recognize a much more radical critique: Manichaean speech is not only the expression of a distended self, but also and importantly the cause of the distended self that would separate wisdom from eloquence in the first place.

\footnotetext{
${ }^{67}$ Augustine, Confessions (trans. Watts), 5.2.

${ }^{68} \mathrm{O}^{\prime}$ Donnell, Confessions, cited in n. 8 above, 2:283.
} 
It is now possible to provide an answer to the "why" question advanced above: Why does Augustine equate loquacity with silence? Because loquacity is the linguistic practice of the distended self, the self that is "coming closer to nothingness." Within Augustine's thought, professors are simply accelerating their own distention into the world and thus undermining the subject position from which they speak. Augustine left his position as a teacher of rhetoric, then, not because his conversion to Christianity suddenly made him aware of the need to unite wisdom with eloquence (he had long known this from Cicero), but rather because his activities as a "professor"in the most literal sense of the word-undermined the possibility that he would ever unite wisdom with eloquence. In other words, Augustine's resignation of the professoriate was not predicated upon a need to append wisdom to an already perfected form of eloquence, but rather upon the need to alter his very form of speech. It is true that Augustine rejected his job as a professor of rhetoric, but this was not a rejection of rhetoric. It was, rather, a rejection of professing itself, for the "professor" by definition could never attain the wisdom Augustine sought.

It is, then, possible to understand Augustine's highly dramatized resignation as a professor of rhetoric as an act undertaken on behalf of rhetoric itself. He recognized that the activity of profession was complicit in the production of dispersed subjects. The more one professed, the more one spread oneself out into the world until there was literally no distinction between the self and the world. The professor was perforce a subject, subject to his or her own loves and thus subject to the obligations of the surrounding world. This, I imagine, is why Augustine insists time and again that loquacity eventuates in silence: loquacity produces subjects so dispersed into the world that they have no ground from which to offer dissent. In other words, because the voice of the professor is equated with the voice of the world which, by definition, goes without saying, the voice of the professor is, functionally speaking, silent.

\section{CONCLUSION}

As Murphy has wisely noted, the sheer scope of Augustine's influence means that "the exact nature of his contribution to rhetorical theory [is] a matter of some importance. ${ }^{\prime \prime 9}$ Reading Augustine's

\footnotetext{
${ }^{69}$ Murphy, "Saint Augustine and the Christianization of Rhetoric," cited in n. 2 above, p. 26.
} 
resignation of the professoriate as an act undertaken on behalf of rhetoric provides the opportunity to revise our most fundamental notions regarding Augustine's contributions to rhetorical theory. Nearly all our commentators emphasize Augustine's insistence that rhetoric should combine wisdom and eloquence. Troup was only reiterating a widely shared belief when he claimed that, for Augustine, "the value of rhetoric [is] to be determined by its association either with wisdom or foolishness." Troup is surely correct. Yet, as I suggested above, it is also repetitive: Cicero and Quintilian made similar claims, as did Plato before them. If this is the extent of Augustine's contributions to rhetorical theory, he may not be worth our reading.

I believe he is worth reading. This is because, in The Confessions, the place of rhetoric is figured not so much by its relationship to wisdom as by its relationship to the self. In other words, it is not the union of wisdom and eloquence that is essential; it is the union of a mode of subjectivity and a mode of speech. Augustine elaborates two possibilities for this relationship: a distended self that professes, and whose professions distend the self; and a gathered self that confesses, and whose confessions gather the self. Yet only one of these possibilities provides a haven for rhetoric. As I argued, profession distends the self and spreads it out into the world. It is thus an immanently compromised rhetorical form; it carries the seeds of its own dissolution because it obliterates the difference between an agent acting in the world and the world acting through an agent. The professor, in other words, grows ever more indistinguishable from the world and ever more unable to act in the world. We might emend Troup then, and suggest that the "value of rhetoric" is determined only secondarily by its association with "wisdom or foolishness." In the first instance, the "value of rhetoric" must be determined by its relationship to a particular subjectivity. If the function of speech is, as Augustine put it in The City of God, to "run between men (sic)," the continued vitality of this function required that Augustine resign his professorship (DCD, VII.14).

Finally, if Augustine's chief contribution to rhetorical theory is the union between modes of subjectivity and modes of speech, this requires that we revise our estimate of The Confessions. In "The Metarhetorics of Plato, Augustine, and McLuhan," James Murphy provides a list of Augustinian texts relevant to the student of rhetoric. $^{70}$ The Confessions is notably absent. If Augustine's contri-

\footnotetext{
${ }^{70}$ Murphy, "The Metarhetorics of Plato, Augustine, and McLuhan," cited in n. 16 above, p. 205.
} 
bution to rhetorical theory is only another iteration of the union of wisdom and eloquence, this absence is justified; for this lesson there is little need to read beyond On Christian Doctrine. Yet if, as I argue, Augustine's primary contribution is his claim that speech be evaluated with recourse to the modes of subjectivity from which it springs, then The Confessions is essential. Indeed, it is no coincidence that this argument is made in The Confessions, for the lesson is that speech-all speech-is fundamentally confessive in the sense that it is best understood in terms of the self from which it springs. 